\title{
РОССИЙСКАЯ И БЕЛОРУССКАЯ МОЛОДЕЖЬ В СТЕРЕОТИПНЫХ ОЦЕНКАХ ДРУГ ДРУГА (РЕЗУЛЬТАТЫ ЭТНОСОЦИОЛОГИЧЕСКОГО ИССЛЕДОВАНИЯ 2018-2020 гг.)*
}

\begin{abstract}
В статье приводятся результаты сравнительного изучения молодежной ментальности двух стран, формирующейся в условиях идеологического и политического пограничья. Уровень взаимопонимания между двумя независимыми государствами во многом зависит от того, насколько молодые поколения адекватно представляют себе национальный характер друг друга, иченностные приоритеты и мировоззренческие позиции своих сверстников, живущих в соседней стране. в работе рассматриваются особенности этнической идентичности молодых людей двух стран, их авто и гетеро стереотипы, исследуется отношение к совместному историческому прошлому и настоящему, изучается наиболее привлекательные у молодых людей страноведческие бренды России и Беларуси. Проблемы установления взаимопонимания молодежи осложняются тем, что обе страны являются наследницами единого советского прошлого, но испытывают определенные трудности в процессе его модернизачии. До недавнего времени для белорусов было характерно стремлением к независимости, для россиян - ориентация на интеграционные прочессы. в последнее время со стороны обеих государств усиливаются интеграционные процессы, связанные с построением Союзного государства, что было вызвано волнениями в Беларуси после президентских выборов в 2020 2. Надо отметить, что наше исследование проводилось раннее августовских событий 2020 г. и показало позитивнье результатьв во взаимодействии и восприятии молодьми людьми друг друга.
\end{abstract}

Ключевые слова: студенческая молодежь, этническая идентичность, самоидентификация, автостереотипь и гетеростереотипь, образ страны, постсоветское пространство, интеграџионные процессы

Для цитирования: Снежкова И.А., Шальгина Н.В. Российская и белорусская молодежь в стереотипных оценках друг друга (результаты этносоциологического исследования 2018-2020 гг.) // Вестник антропологии, 2021. № 4. С. 283-296.

Три десятилетия, прошедшие с момента распада СССР, обозначили множество новых проблем, связанных с поисками взаимопонимания и сотрудничества между

Снежкова Ирина Анатольевна - к.и.н., старший научный сотрудник, Институт этнологии и антропологии РАН (119991 Москва, Ленинский просп., 32а). Эл. почта: snezhkova@mail.ru

Шалыгина Наталья Валентиновна - к.и.н., старший научный сотрудник, Институт этнологии и антропологии РАН (119991 Москва, Ленинский просп., 32a). Эл. почта: etgender@mail.ru 
бывшими союзными республиками. На сегодняшний день Россия ведет разнонаправленную политику в отношении каждой из республик, стремясь к построению долгосрочной политики добрососедства на всем постсоветском пространстве. И, несмотря на все имеющиеся проблемы политического, экономического и социокультурного свойства, этот процесс продолжает развиваться в поступательном направлении, объединяя интересы уже суверенных государств. в сложившейся ситуации большое (если не решающее) значение приобретает восприятие молодежью обеих стран ментальных особенностей соседей, которые, несмотря на долгие годы совместного исторического пути, в течение последние трех десятков лет развивались на различных идейно-экономических платформах. За этот период выросло новое поколение, чьи ценности впитали в себя с одной стороны принципы технократической глобализации, а с другой принципы самостоятельных, суверенных государств, ориентирующихся на свой собственный путь развития.

Проблема состоит в том, насколько эти новые поколения двух генетически и исторически близких друг другу славянских народов, разъединенных катаклизмами политических событий, окажутся способными в новых условиях найти общий язык друг с другом. в качестве гипотезы рассматривается утверждение, что за длительный период совместной истории и особенно за период советского времени (1920-е гг. - 1991 гг.) у обоих соседних народов сформировались не просто сходные ценности общечеловеческого плана, но и сходная ментальность, которая транслировалась молодым поколениям и создавала архетипические модели поведения, мировосприятия, традиции повседневного быта и т.п.

Проверка данной гипотезы стала одной из задач совместного российско-белорусского исследования 2018-2020 гг., проводившегося силами совместной исследовательской группы преподавателей Белорусского государственного университета (БГУ) и научными сотрудниками Института этнологии и антропологии им. Н.Н. Миклухо-Маклая Российской академии наук (ИЭА РАН). Основным методическим инструментом исследования стала анкета, включившая в себя 40 вопросов, касающихся, изучения национальной идентичности, стереотипов восприятия соседнего народа, идентификации символов двух стран, осознания сходства и различий русских и белорусов, степень информированности студенческой молодежи России и Беларуси друг о друге, с точки зрения политических, экономических и культурных особенностей, оценка исторических событий в период существования обеих народов в составе Киевской Руси, Московского княжества, Российской империи, СССР, и в Независимых государствах. Для получения максимально правдивой информации одновременно были использованы открытые и закрытые вопросы. в общей сложности анкетированием удалось охватить 500 студентов - 250 человек в БГУ и 250 человек в нескольких российских вузах г. Москвы. Так, в опросе участвовали такие вузы Москвы, как Московский государственный технический университет им. Н.Э. Баумана (МГТУ им. Н.Э. Баумана), Московский инженерно-физический институт (МИФИ), Институт журналистики и литературного творчества (ИЖЛТ), Российский государственный гуманитарный университет (РГГУ), Институт социальной инженерии Российского гуманитарного университета им. А.Н. Косыгина (ИСИ РГУ), Московская Финансово-юридическая академия (МФЮА), Московский технический институт связи и информатики (МТУСИ), Московский государственный университет технологий и управления им. К. Г. Разумовского (ПКУ). 
Кроме того, для выявления толерантности/интолерантности российских и белорусских студентов по отношению друг к другу как к носителям другой этнической принадлежности были использованы этнопсихологические методы, например, метод К. Каца и К. Брейли, позволивший определить авто- и гетеростереотипы в сознании студентов (Стефаненко 1987: 242-250). С этой же целью в исследовании применялся и модифицированный тест М. Куна и Т. Макпартленда «Кто я?», разработанный авторами еще в середине прошлого века в рамках направления символического интеракционизма (Чикагская школа), и в данном случае позволивший составить представление об особенностях личностной самоидентификации современной студенческой молодежи, включая социальные, гендерные, общегражданские и этнические параметры (Khun 1951: 68-76).

На первом этапе исследования был использован модифицированный тест М. Куна и Т. Макпартленда, следуя которому российским и белорусским студентам было предложено в иерархическом порядке заполнить 6 позиций, касающихся их Я-концепции. Категории своей индивидуальной Я-концепции и последовательность их расположения на условной шкале ценностей каждый студент должен был определить для себя самостоятельно. Задача тестирования состояла в том, чтобы выявить значимость для студенческой молодежи ценности статусной иерархии в обществе и определить выбор респондентами собственных категорий самоидентификации, к ним относились следующие позиции - общечеловеческий статус «я - человек», гендерный статус («я - девушка», «я - парень»), социальный статус («я - студент»), гражданский статус («я - гражданин России» или «я - гражданин Беларуси»), религиозный статус («я - христианин»), этнонациональный статус («я - русский»), личностный статус («я - личность» или «я - индивид») и статус в семейно-родственной структуре («я дочь» или «я - сын»). Итоги тестирования представлены на рисунке 1.

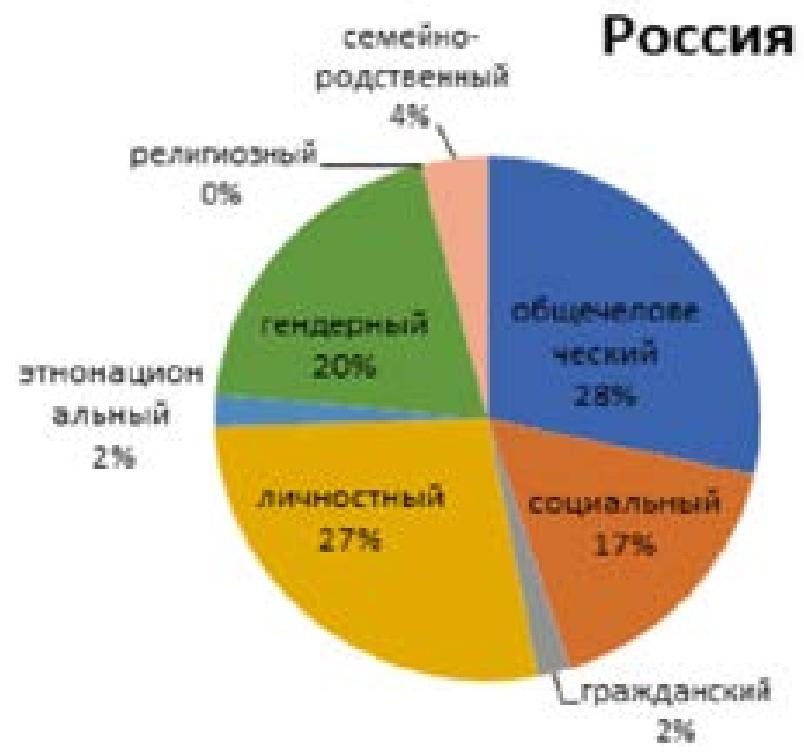

Рис. 1. Приоритеты студенческой молодежи в сфере статусной иерархии (\%).

Для большинства респондентов обеих групп наиболее важным определением их «Я-концепции» оказался общечеловеческий статус - «я - человек» (соответственно 
$52 \%$ в белорусской группе и $29 \%$ в российской группе). На втором месте по числу респондентов, отдавших предпочтение этой статусной позиции, в белорусской группе оказался социальный статус, или принадлежность к студенческому сообществу $(16 \%)$, а в российской - личностный статус (28\%). На третьем месте в обеих группах респондентов - гендерный статус (12\% ответивших в белорусской группе и $20 \%$ - в российской). На четвертом месте в белорусской группе - гражданский и личностный статус поровну из числа ответивших ( $8 \%$ и $8 \%)$, а в российской группе - социальный статус (17\%). Наименее значимыми позициями «Я-концепции» для белорусских студентов оказались религиозность и роль в семейной структуре, которым отдали предпочтение по 4\% респондентов, а для российских студентов - этно-национальный статус $(2 \%)$ и также роль в семейно-родственной структуре $(2 \%)$. К этому можно добавить, что религиозный статус как важную позицию «Я-концепции» в российской группе респонденты не отметили вовсе, а в белорусской группе респонденты вообще проигнорировали позицию этно-национального статуса.

Таким образом, несмотря на различия в соотношении статусных показателей, очевидно, что и для белорусских, и для российских студентов наиболее важной позицией в «Я-концепции» являются такие показатели, как общечеловеческий статус, личностный, социальный и гендерный. Как видно из рисунка, показатели гражданственности, религиозности и принадлежности к той или иной национальности не являются для молодежи обеих стран приоритетными. Иными словами, результаты опроса молодежи двух стран показали, что конкретные общечеловеческие ценности (семья, любовь, дружба и т.п.) в системе ценностей молодежи обеих стран являются абсолютным приоритетом и по своей значимости для самой молодежи значительно превосходят любые абстрактные понятия, связанные с представлениями об этнической принадлежности, национальности, что радует особенно, когда мы сталкиваемся с выраженным национализмом на Украине.

\section{Этнические авто- и гетеростереотипы российской и белорусской молодежи}

Этнические автостереотипы, согласно концепции, разработанной исследователями Принстонского университета Д. Кацом и К. Брейли (США), понимаются как образы этнической группы, сформированные ее носителями о самих себе, а этнические гетеростереотипы - как образы представителей одной этнической группы о других этнических группах (Katz 1933: 280-290). Как правило, этнические автостереотипы (АС) более информационно насыщены и, чаще всего, позитивны, в то время, как гетеростереотипы (ГС) носят несколько упрощенный характер и могут быть менее позитивными или даже негативными. Задача исследовательской группы на данном этапе состояла в том, чтобы, во-первых, определить характер представлений российской и белорусской молодежи о самих себе как о носителях определенной культуры, а, во-вторых, выяснить степень осведомленности молодежи обеих стран друг о друге. С этой целью в анкету были включены открытые вопросы, позволяющие респондентам самим формулировать те качества, которые, по их мнению, более всего характеризуют русский и белорусский народы.

При анализе ответов на вопросы анкеты была использована матричная структура характерологических свойств личности, разработанная советским и российским исследователем В.Н. Панферовым (Панферов 2000: 168). Суть данной структуры заклю- 
чается в том, что общий массив полученных в результате анкетирования характеристик разделяется на несколько смысловых категорий, позволяющих добиться максимально точного и адекватного сопоставления стереотипных представлений респондентов. Каждая смысловая категория, выделенная в массиве стереотипных представлений респондентов, согласно поставленной задаче, имеет как положительные, так и отрицательные коннотации. Используя принципы создания матричной структуры личности, мы получили возможность сравнить стереотипные представления белорусской и российской молодежи как о самих себе (АС - автостереотипы), так и друг о друге (ГС - гетеростереотипы) по нескольким параметрам. Результаты сведены к дихотомным значениями и представлены ниже со знаком «плюс» или со знаком «минус».

Таблица 1

\section{Основные категории стереотипных представлений российских и белорусских студентов о национальном характере друг друга}

Характерологический стиль поведения

\begin{tabular}{|c|c|c|c|c|}
\hline & \multicolumn{2}{|c|}{ Россияне } & \multicolumn{2}{|c|}{ Белорусы } \\
\hline & плюс & минус & плюс & минус \\
\hline $\mathbf{A C}$ & $\begin{array}{c}\text { Стремление } \\
\text { к справедливости }\end{array}$ & Безответственность & Альтруизм & Безотказность \\
\hline ГC & Целеустремленность & & Порядочность & Непритязательность \\
\hline
\end{tabular}

Деятельностный стиль поведения

\begin{tabular}{|c|c|c|c|c|}
\hline & \multicolumn{2}{|c|}{ Россияне } & \multicolumn{2}{|c|}{ Белорусы } \\
\hline & плюс & минус & плюс & минус \\
\hline $\mathbf{A C}$ & Адаптивность & $\begin{array}{c}\text { Неуверенность } \\
\text { Принцип «авось» }\end{array}$ & Трудолюбие & $\begin{array}{l}\text { Избыточное } \\
\text { послушание }\end{array}$ \\
\hline ГC & Активность & $\begin{array}{c}\text { Ощущение } \\
\text { вседозволенности }\end{array}$ & Трудолюбие & $\begin{array}{c}\text { Склонность } \\
\text { к подчинению }\end{array}$ \\
\hline
\end{tabular}

Доминирующие личностные характеристики

\begin{tabular}{|c|c|c|c|c|}
\hline & \multicolumn{2}{|c|}{ Россияне } & \multicolumn{2}{|c|}{ Белорусы } \\
\hline & плюс & минус & плюс & минус \\
\hline $\mathbf{A C}$ & $\begin{array}{c}\text { Душевность } \\
\text { Щедрость }\end{array}$ & Беспомощность & Миролюбие & $\begin{array}{c}\text { Излишняя } \\
\text { терпеливость }\end{array}$ \\
\hline$\Gamma \mathbf{C}$ & Широкая душа & Имперское сознание & Миролюбие & Пассивность \\
\hline
\end{tabular}

Стиль построения межличностных отношений

\begin{tabular}{c|c|c|c|c}
\hline \multirow{2}{*}{} & \multicolumn{2}{|c|}{ Россияне } & \multicolumn{2}{c}{ Белорусы } \\
\cline { 2 - 5 } AC & Дружелюбие & Слабохарактерность & Бесконфликтность & Птеснительность \\
\hline \multirow{2}{*}{ ГC } & $\begin{array}{c}\text { Отзывчивость } \\
\text { Коммуникабельность }\end{array}$ & Импульсивность & Доброжелательность & $\begin{array}{c}\text { Чрезмерное } \\
\text { спокойствие }\end{array}$ \\
\hline
\end{tabular}


Наличие/отсутствие волевых качеств

\begin{tabular}{|c|c|c|c|c|}
\hline & \multicolumn{2}{|c|}{ Россияне } & \multicolumn{2}{|c|}{ Белорусы } \\
\hline & плюс & минус & плюс & минус \\
\hline $\mathbf{A C}$ & $\begin{array}{l}\text { Отважность } \\
\text { Сила }\end{array}$ & Ожесточенность & Уверенность & Боязливость \\
\hline$\Gamma \mathrm{C}$ & Храбрость & Безбашенность & Уравновешенность & $\begin{array}{c}\text { Нежелание отстаи- } \\
\text { вать свои права }\end{array}$ \\
\hline
\end{tabular}

Социально значимые характеристики

\begin{tabular}{|c|c|c|c|c|}
\hline & \multicolumn{2}{|c|}{ Россияне } & \multicolumn{2}{|c|}{ Белорусы } \\
\hline & плюс & минус & плюс & минус \\
\hline $\mathbf{A C}$ & $\begin{array}{c}\text { Патриотизм } \\
\text { Сплоченность } \\
\text { Самопожертвование }\end{array}$ & Вспыльчивость & Патриотизм & $\begin{array}{c}\text { Сильная подчинен- } \\
\text { ность власти }\end{array}$ \\
\hline$\Gamma \mathrm{C}$ & Гордость & Самомнение & $\begin{array}{c}\text { Преданность } \\
\text { традиционным } \\
\text { ценностям }\end{array}$ & $\begin{array}{c}\text { Отсутствие стремле- } \\
\text { ния к изменениям }\end{array}$ \\
\hline
\end{tabular}

Эмоциональные характеристики

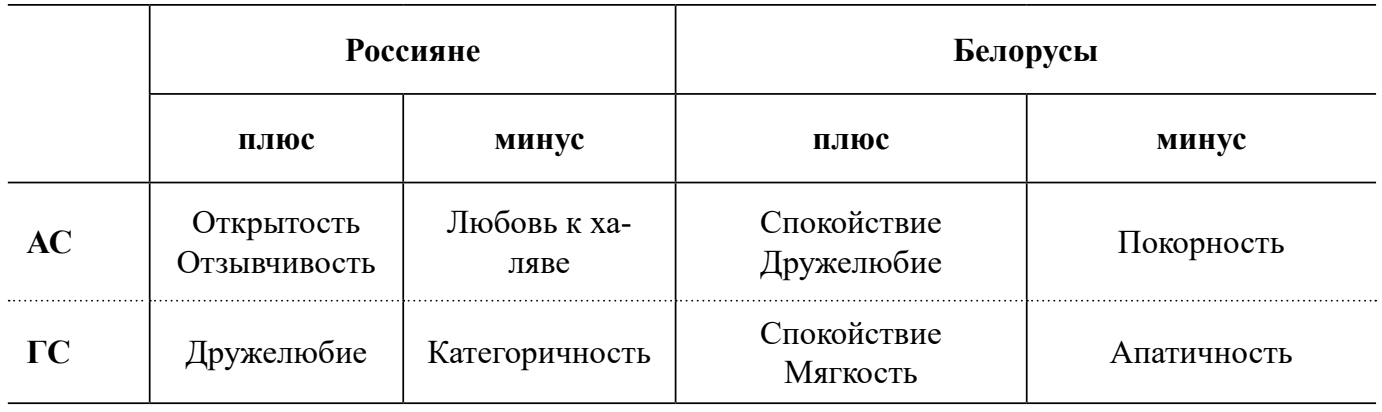

Исходя из приведенных значений, можно сделать несколько выводов. Во-первых, степень информированности российских и белорусских студентов друг о друге достаточно высока, о чем свидетельствует разнообразие направлений, формирующих мнение молодежи друг о друге. Респонденты обеих групп в своих ответах затронули практически полный спектр значений, составляющих эмоционально-деятельностный портрет соседнего народа. Во-вторых, совпадение большинства значений (как положительных, так и условно отрицательных) свидетельствует о высоком потенциале взаимопонимания молодежи, в противовес политическим и экономическим разногласиям во властных структурах обеих стран. К этому можно добавить, что дальнейшему укреплению взаимопонимания молодежи в немалой степени способствует и то обстоятельство, что и у российских, и у белорусских респондентов, принимавших участие в нашем исследовании, в каждой из соседних стран проживает достаточно большое количество родственников, с которыми молодежь на сегодняшний день поддерживает активные отношения. Немаловажную роль играют СМИ, особенно для Беларуси, где активно смотрят российское телевидение. 
И, наконец, в-третьих, количество положительных характеристик соседнего народа, как у белорусских, так и у российских студентов, минимум в 2 раза превышает количество отрицательных, хотя вопрос в анкете был сформулирован достаточно нейтрально - «Что Вам нравится и что не нравится в россиянах? в белорусах?». Важно и то, что оскорбительная тональность характеристик (например, «все русские - любят выпить») как стереотип восприятия другого народа среди ответов наших респондентов не встречается. Оценочный негатив белорусских студентов в адрес своих российских сверстников в самых крайних случаях выглядит следующим образом: «мажоры, упертые (упрямые), слишком громкие, вычурные, склонные к доминированию и т.п.). И, наоборот, российские студенты, отмечая те черты, которые им не нравятся в белорусах, в отдельных случаях писали, что это «чрезмерное спокойствие, страх говорить правду, зависимость и т.п.». На наш взгляд, подобного рода ответы свидетельствуют лишь о том, что молодежь обеих стран не безразлична друг к другу и способна достаточно тонко улавливать особенности национального характера соседнего народа.

\section{Восприятие российскими и белорусскими студентами образа обеих стран}

На формирование образа страны, согласно сегодняшним представлениям, сложившимся в сфере имиджелогии, влияет, как минимум, две группы факторов, которые чаще всего подразделяются на «условно-статичные», т.е., оставшиеся в прошлом, и «условно-динамичные», т.е., влияющие на процесс формирования образа страны в настоящее время. Вопросы анкеты, предложенной для заполнения российским и белорусским студентам, в нашем исследовании были ориентированы на две вышеуказанные группы факторов. в свою очередь, в каждой из групп факторов в обязательном порядке учитывалась возможность как позитивных, так и негативных ответов. Результаты анкетирования представлены ниже.

Восприятие исторических событий с участием России и Беларуси (условно-статичные факторы). На вопрос «Как Вы оцениваете роль России в истории Беларуси?» $41 \%$ белорусских студентов ответили, что положительно, $12 \%$ - отрицательно и $47 \%$ затруднились с ответом. Большой процент белорусских респондентов, затруднившихся с ответом на этот вопрос, объясняется, прежде всего, тем, что представители этого поколения, родившихся в 2000-е годы, учат историю по учебникам, написанным в непростое время разрушения идеологического единства, существовавшего почти 70 лет между республиками бывшего СССР, и создания новых, так называемых, альтернативных версий исторических событий. Формирование в сознании этого поколения новых версий причинно-следственных связей в истории России и Беларуси оказалось достаточно запутанным и не всегда отражающим реальное положение дел. в таблице, приводимой ниже, показано, как именно сегодня студенты обеих стран оценивают свою совместную историю.

Сразу же можно сказать, что относительное однообразие ответов российских респондентов по этому вопросу связано с тем, что история взаимоотношений России и Беларуси не только не входит в программу сегодняшних учебников по истории, но не была представлена в должной мере и в советских программах обучения по предмету «история». Причина проста: школьные программы и большинство вузовских программ рассматривали отечественную историю как единую для всех народов 
СССР. Упоминание о героях-белорусах, как и о героях других республик Советского Союза, а также любые достижения и победы представителей республик считались частью общей истории страны. Без преувеличения можно сказать, что российская молодежь мало знает о событиях, непосредственно касающихся Беларуси. Тем не менее, абсолютное большинство ответов российских респондентов со знаком «плюс» по поводу указанных исторических событий, во-первых, свидетельствует о том, что все, связанное с Беларусью в общей истории обеих стран, воспринимается самой российской молодежью однозначно позитивно, а, во-вторых, не вызывает, по сути, никаких дополнительных вопросов, как бы это ни оценивалось.

Таблица 2

\section{Отношение белорусских и российских студентов к событиям их совместной истории}

\begin{tabular}{|c|c|c|c|c|c|c|}
\hline \multirow{2}{*}{$\begin{array}{l}\text { Основные } \\
\text { исторические события }\end{array}$} & \multicolumn{3}{|c|}{ Белорусские студенты } & \multicolumn{3}{|c|}{ Российские студенты } \\
\hline & Плюс & Минус & Не знаю & Плюс & Минус & Не знаю \\
\hline Киевская Русь & $75 \%$ & $14 \%$ & $11 \%$ & $79 \%$ & $2 \%$ & $19 \%$ \\
\hline Московское княжество & $32 \%$ & $57 \%$ & $11 \%$ & $75 \%$ & $2 \%$ & $22 \%$ \\
\hline $\begin{array}{l}\text { Белоруссия в составе } \\
\text { Российской империи }\end{array}$ & $29 \%$ & $68 \%$ & $3 \%$ & $83 \%$ & $1 \%$ & $16 \%$ \\
\hline Белоруссия в составе СССР & $75 \%$ & $25 \%$ & - & $80 \%$ & $3 \%$ & $17 \%$ \\
\hline Независимое государство & $93 \%$ & $7 \%$ & - & $83 \%$ & $10 \%$ & $7 \%$ \\
\hline
\end{tabular}

Иная картина в белорусской группе наших респондентов. Ответы студентов на поставленный в анкете вопрос («Укажите Ваше отношение к историческим событиям в процессе взаимодействия российского и белорусского народов»), не только существенно различаются между собой, но и сопровождаются достаточно пространными комментариями. Так, среди тех респондентов, чьи ответы даны со знаком «плюс», прослеживается желание объяснить, почему именно союз с Россией для Беларуси в различные исторические эпохи оказывался весьма благотворным. в период существования Киевской Руси, например, как считают 75\% наших белорусских респондентов, на территории будущего государства Беларусь «...происходило активное развитие городов..., которые получали не только экономические стимулы к развитию, но и защиту со стороны князей Киевской Руси от врагов». Оценка белорусскими студентами особенностей того исторического периода, однако, далека от какого-либо приукрашивания реальности: «...раздельно белорусов и русских в то время не существовало...»; «... все государственные образования, в которые входила Беларусь, помогли ей стать такой, какая она есть, несмотря на трудности, которые ей приходилось переживать при вхождении в эти государственные образования...»; «... ну, а куда ж без Руси-то?» и т.п.

Период существования Великого княжества Московского (XIV-XV вв.) 32\% белорусских респондентов описали как время формирования общих традиций и обычаев. Однако, при характеристике белорусскими студентами этого исторического периода все-таки доминируют негативные оценки, с точки зрения влияния Московского 
государства на развитие Беларуси (57\%). Так, некоторые респонденты сожалеют о введении православия, в противовес католичеству, вынужденное участии Беларуси в войнах, разоряющих страну, отмечают признаки культурной конфронтации и т.П.

Оценка развития Беларуси в составе Российской империи, с точки зрения 29\% белорусских респондентов, была вполне позитивна. Студенты указывают важность проводимых Россией реформ (придание школе светского характера, введение Белорусского учебного округа, введение народных школ и т.п.). Тем не менее, именно этот исторический период отмечен наибольшим числом негативных оценок в белорусских анкетах (68\%). Объясняется такое положение дел, по-видимому, тем, что в этот период Россия значительно усилила свое участие в развитии социально-экономической сферы Беларуси, с целью не допустить распространение здесь польского влияния (Карев 2015 : 203-209) А, если учесть, что сегодня Польша рассматривается белорусской оппозицией как наиболее значимый «агент влияния» в продвижении евроатлантических ценностей на территории республики Беларусь (Политика 2015: 18-25), то исторический прецедент, вполне возможно, воспринимается молодежью достаточно ангажировано и способен непосредственно влиять на ее отношение к современной России.

Советский период, напротив, вызывает у белорусской молодежи преимущественно позитивные ассоциации (75\%). С этим периодом наши респонденты связывают бурное развитие промышленности на территории Белоруссии, высокий уровень образования и «неплохой уровень жизни».

Победу в Великой Отечественной войне (1941-1945 гг.) абсолютное большинство белорусских студентов относит к категории исторических событий, которыми страна может и должна гордиться (85\%). При этом, комментарии самих белорусских респондентов демонстрируют осознанное восприятие победы в ВОВ и полное понимание значения этого события: «гордость за предков», «радость для двух наших народов», «мощь объединенного народа», «эта Великая победа обеспечила будущее моей стране и моему поколению», «это одно из самых значительных событий в истории белорусского народа» и т.д.

Независимое государство приветствует $83 \%$ россиян и $93 \%$ белорусов. Среди россиян большое количество молодых людей, которые ценят появление свободного от коммунистического прошлого государства, но сожалеют о распаде СССР, что привело к появлению новых государственных объединений не всегда дружественных России. Белорусы рады независимому государству, падению коммунистического режима, обретению новых прав и свобод (Снежкова 2020: 17-41).

Относительно Союзного государства $57 \%$ россиян видят в этом положительное явление. Белорусы первоначально более настороженно относились к этому процессу, боясь потери независимости, попадания под санкции коллективного Запада, которые распространяются на Россию, но в результате волнений в Беларуси после президентских выборов 2020 г, отношение изменилось в сторону поддержки Союзного государства.

Из всего сказанного можно сделать как минимум 2 вывода. Во-первых, совместная история двух соседних народов белорусскую молодежь интересует значительно больше, чем российскую. И, во-вторых, исторические события для белорусских студентов, судя по всему, являются полем идеологических споров и оказывают неоднозначное влияние на формирование образа России в целом. 
Однако условно-статистические факторы (т.е. представляющие собой некую постоянную, неизменную величину), влияющие на формирование образа страны, не исчерпываются только историческими событиями. К категории таких факторов относится, например, и геополитическое положение, и потенциал природных ресурсов страны, и культурное наследие. С целью получения максимально свободных ответов об конкурентно-аутентичных преимуществах России и Беларуси, в нашу анкету был включен открытый вопрос, посвященный созданию основных брендов каждой из стран. Причем, обеим группам респондентов предоставлялась возможность создать рекламный контент образа как своей, так и соседней страны.

Белорусский вариант рекламного контента (белорусские студенты о символах Беларуси и России)

Беларусь

- природные характеристики: «синеокая озерная страна», чистый воздух, «аисты летают», красивый ландшафт: «страна-василек», нетронутая природа;

- культурные характеристики: средневековые замки, рыцарские бои, культовые сражения, развитые ремесла;

- исторические характеристики: Киевская и Московская Русь, белорусы в составе, Литовского княжества и Речи Посполитиой, Российская империя, СССР, Независимое государство;

- экономические характеристики: развитое сельское хозяйство, Белаз, Маз;

- образ жизни: счастливая семья, стабильность, низкие цены, многочисленные санатории и базы отдыха.

Россия

- природные характеристики: огромные природные богатства, необъятная тайга, реки, моря и океаны;

- культурныле характеристики: Московский Кремль, архитектура Санкт-Петербурга, знаменитые писатели и художники;

- исторические характеристики: Российская империя, СССР, Российская Федерация, Союзное государство;

- экономические характеристики: нефть, газ;

- образ жизни: культура различных наций, огромные возможности для самореализации.

\section{Российский вариант рекламного контента (российские студенты о символах Беларуси и России)}

Беларусь

- природные характеристики: чистая природа, озера, Беловежская Пуща, зубры;

- культурные характеристики: «Славянский базар», «Песняры», Би 2;

- исторические характеристики: Великая Отечественная война, партизаны, Брестская крепость;

- экономические характеристики: сельское хозяйство, колхозы, фермы, Белаз;

- 


\section{Россия}

- природные характеристики: озеро Байкал, Сибирь, Кавказ, Волга, медведи;

- культурные характеристики: Москва, Санкт-Петербург, Золотое кольцо, народные промыслы, писатели, художники;

- исторические характеристики: победа над Наполеоном, победа в Великой отечественной войне, СССР, полеты в космос, Российская Федерация;

- экономические характеристики: нефть, газ, космическая отрасль;

- образ жизни: динамическая жизнь, возможности для реализации, неспокойная политическая ситуация.

Приведенные примеры восприятия всего лучшего, что есть в своей собственной и в соседней стране, свидетельствуют о том, что как у белорусских, так и у российских респондентов представления о национальных достижениях обеих стран носят достаточно положительный характер.

\section{Восприятие белорусской и российской молодежью актуальных событий современности}

К категории условно-динамичных факторов формирования образа страны относятся те факторы, которые способны оказывать корректирующее влияние на этот процесс - экономические, политические, социальные и др. в нашей анкете была поставлена задача определить степень медийного влияния на восприятие молодежью образа Беларуси и России. Респондентам обеих групп был задан вопрос о том, какую роль играют средства массовой информации в формировании образа России и Беларуси. Кроме того, в анкету был включен и вопрос о том, каким средствам массовой информации студенты доверяют больше - российским, белорусским или западным, когда речь заходит о России и Беларуси. И такая формулировка была выбрана не случайно. По словам Игоря Бузовского, замглавы администрации Президента Белоруссии, российский контент в белорусских СМИ сегодня достигает 65\% (Рункевич 2019), что составляет серьезную конкуренцию национальным СМИ страны.

Согласно результатам нашего анкетирования, 53\% белорусской молодежи не доверяет никаким средствам массовой информации. Чуть меньший процент в качестве основного источника информации предпочитают российские СМИ (34\%), западным же СМИ доверяют менее $13 \%$ белорусских студентов. Активизация оппозиционных интернет-изданий (Хартия-97) на белорусских порталах, согласно комментариям наших белорусских респондентов, также не вызывает у них живого интереса. Проведенный в Минске в декабре 2018 г. опрос российской социологической службой «Левада-Центр» белорусских студентов по поводу их включенности в обсуждение политических проблем, показал, что основная масса учащейся белорусской молодежи аполитична - менее $10 \%$ студентов хотели бы каких-либо политических перемен (Левада-центр 2018). Наши белорусские респонденты, комментируя вопросы о влиянии на них СМИ, написали, что вообе плохо понимают, что-такое политика, что их гораздо больше интересует возможность просто съездить на выходные в Литву, а не посещать политически настроенные молодежные кружки (например, молодежный образовательный центр Фиальта). Однако после событий, связанных с выборами президента Лукашенко в августе 2020 г. ситуация резко изменилась. Деятельность оппозиционных СМИ и сетевых сообществ, расположенных в Литве и 
Польше, курируемых из дальнего зарубежья приобрела ведущее положение. Самый популярный Телеграм канал NEXTA был посвящен протестам в Беларуси и быстро завоевал популярность среди молодежи, но также быстро его деятельность сошла на нет, особенно после задержания его основателя Р. Протасевича.

Что касается российской молодежи, то влияние официальных СМИ на их отношение к своим белорусским сверстникам и в целом к Беларуси, согласно результатам нашего анкетирования, также оказалось минимальным: $83 \%$ российских студентов ответили, что не интересуются политическими вопросами отношений России и Беларуси.

Как уже отмечалось, наше исследование проводилось до августовских волнений 2020 г., связанных с выборами президента Беларуси. Эти события сделали актуальными многие вопросы. в частности, какие факторы влияют на поведение оппозиции в стране, внутренние или внешние? Как быстро меняется настроение общества, были ли весомые предпосылки для массовых протестов раннее, или подаваемый материал в СМИ не достаточно объективный. Все эти проблемы требуют дальнейших исследований российско-белорусских отношений.

\section{Выводы}

Подводя итоги проведенному исследованию, мы пришли к следующим выводам:

1. Ментальность российских и белорусских студентов имеет общую основу, ориентированную на конкретные общечеловеческие ценности (семья, любовь, дружба и т.д.). Вопросы, связанные с принадлежностью к той или иной национальности, а также обсуждение их в дискуссиях (включая дискуссии в блогосфере) для обеих групп молодежи оказываются значительно менее интересными, чем общение на уровне актуальных проблем современного поколения (учеба, путешествия, развлечения и т.п.).

2. Стереотипы восприятия российскими и белорусскими студентами друг друга носят преимущественно позитивный характер. Вместе с тем, в процессе нашего исследования было отмечено, что студенческая молодежь обеих стран достаточно точно формулирует особенности национального характера друг друга, что свидетельствует о высоком потенциале взаимопонимания между ними.

3. Со слов молодых людей обеих стран взаимодействие российского и белорусского народа на протяжении различных исторических периодов в целом носит позитивный характер.

4. Представления россиян и белорусов об основных страноведческих брендах России и Беларуси свидетельствуют о хорошем знании и отношении к соседней стране в культурном, экономическим и историческом контексте.

5. Молодежь обеих стран дорожит нахождением в составе независимых государств, но в случае обострения политической ситуации внутри и вовне страны с пониманием относится к построению политического и экономического союза России и Беларуси.

\section{Источники и материалы}

Левада-центр - Левада-центр https://thinktanks.by/publication/2018/12/10/iz-za-chegobelorusskaya-molodezh-stala-appolitichnoy.html (дата обращения 10.10.2021) 


\section{Научная литература}

Гузенкова T.C. и др. Политика Евросоюза в отношении стран постсоветского пространства в контексте евразийской интеграции // Проблемы национальной стратегии, 2015. № 2 (29). С. 18-25.

Карев Д.В. Белорусско-польское сотрудничество в области исторических исследований конца XX - нач. XXI в.: Гродно - Белосток (наработанные традиции и нереализованные перспективы) // Шлях да ўзаемнасці = Droga ku wzajemnoci. Матэрыялы XX міжнароднай навуковай канферэнцыі, Гродна, 23-24 кастр. 2014. Мінск: Строй-Медыя-Праект, 2015. С. 203-209.

Панферов В.Н. Интегративный подход к психологии человека // Психология человека: интегративный подход. СПб: Изд. РГПУ им Герцена, 2000 С. 168

Рункевич Д., Малай Е. Минск увидел угрозу в российских новостях // Русская планета 2019. https://rusplt.ru/society/ugroza-rossiyskih-smi-v-belorussii-24976.html (дата обращения 10.10.2021)

Снежкова И.А. Образы России и Беларуси в представлении молодежи двух стран в контексте геополитических изменений // Образы России и Беларуси в представлениях молодежи двух стран в XXI веке / под ред. И.А. Снежковой, Н.В. Шалыгиной. М.: ИЭА РАН. 2020. С. 17-41.

Стефаненко Т.Г. Социальные стереотипы и межэтнические отношения. М.: Изд-во Моск. ун-та, 2008. С. $242-250$.

Katz D., Braly K. W. Racial stereotypes of one hundred college students // Journal of Abnormal and Social Psychology. 1933. Vol. 28. Pp. 280-290.

Kuhn, Manford and McPartland, T.S. «An Empirical Investigation of Self-Attitudes", American Sociological Review. 1951, Vol. 19. Pp. 68-76.

Snezhkova, Irina A., and Natalia V. Shalygina

\section{Russian and Belarussian Youth in Stereotypical Assessments of Each Other (Results of an Ethno-Sociological Study, 2018-2020)}

\section{DOI: $10.33876 / 2311-0546 / 2021-4 / 283-296$}

The article presents the results of a comparative study of the youth's mentality in Russia and Belarus - two neighboring countries sharing much of their ideology and politics. The mutual understanding between the two independent states largely depends on the adequacy in perceiving by the younger generations of each other's national character, value priorities, and outlook of their peers in the neighboring country. The paper examines the ethnic identity of young people of the two countries, their auto-and hetero stereotypes, their attitude to the common historical past and present of Russia and Belarus; the countries' images the young people find the most attractive are looked upon as well. The problems of establishing mutual understanding among young people are complicated by the fact that both countries are heirs to a common Soviet past, and both experience certain difficulties in the process of their modernization. Until recently, Belarussians were characterized by a desire for independence, while Russians were oriented to the interstate integration processes. Recently, integration processes related to the construction of the Russia-Belarus Union State have been intensifying in both states, accelerated by the unrest in Belarus that broke out after the presidential elections in 2020. It should be noted that our study had been conducted before the events of August 2020, and it revealed favorable perceptions of and attitudes to each other of the Russian and Belorussian youth.

Keywords: students, ethnic identity, self-identification, autostereotypes and heterostereotypes, image of the country, post-Soviet space, integration processes 
For citation: Snezhkova, I.A., Shalygina, N.V. Russian and Belarussian Youth in Stereotypical Assessments of Each Other (Results of an Ethno-Sociological Study, 20182020). Herald of Anthropology (Vestnik Antropologii) 4: 283-296.

Author Info: Snezhkova, Irina A. - PhD (hist.), Senior Researcher, Institute of Ethnology and Anthropology RAS (Moscow, Russia).E-mail: snezhkova@mail.ru

Shalygina, Natalya V. - PhD (hist.), Senior Researcher, Institute of Ethnology and Anthropology RAS (Moscow, Russia).E-mail: etgender@mail.ru

\section{References}

Guzenkova T.S. et.al. 2015. Politika Evrosoiuza v otnoshenii stran postsovetskogo prostranstva v kontekste evraziiskoi integratsii [EU policy towards the post-Soviet countries in the context of Eurasian integration]. Problemy natsional'noi strategii (29): 18-25.

Karev, D.V. 2015. Belorussko-pol'skoe sotrudnichestvo v oblasti istoricheskikh issledovanii kontsa XX - nach. XXI v.: Grodno - Belostok (narabotannye traditsii i nerealizovannye perspektivy) [Belarusian-Polish cooperation in the field of historical research of the late XX - early XX century. XXI century: Grodno - Bialystok (established traditions and unrealized prospects] In Shliakh da y̆zaemnastsi = Droga ku wzajemnoci. Materyialy XX mizhnarodnai navukovai kanferentsyi [The path to reciprocity $=$ The road to reciprocity. Materials of the XX International Scientific Conference], Grodna, 23-24 kastr. 2014, 203-209. Minsk: Stroi-Medyia-Praekt.

Katz, D., and K.W. Braly. 1933. Racial stereotypes of one hundred college students. Journal of Abnormal and Social Psychology 28: 280-290.

Kuhn, M. and T.S. McPartland. 1951. An Empirical Investigation of Self-Attitudes. American Sociological Review 19 (1951): 68-76.

Panferov, V.N. 2000. Integrativnyi podkhod k psikhologii cheloveka [Integrative approach to human psychology] In Psikhologiia cheloveka: integrativnyi podkhod [Human Psychology: integrative approach]. Sant-Petersburg: Izdatelstvo Herzen Russian State Pedagogical University.

Runkevich, D., Malai E. 2019. Minsk uvidel ugrozu v rossiiskikh novostiakh [Minsk saw the threat in the Russian news]. Russkaia planeta. https://rusplt.ru/society/ugroza-rossiyskih-smiv-belorussii-24976.html.

Snezhkova, I.A. 2020. Obrazy Rossii i Belarusi v predstavlenii molodezhi dvukh stran v kontekste geopoliticheskikh izmenenii [Images of Russia and Belarus in the representation of the youth of the two countries in the context of geopolitical changes] In Obrazy Rossii i Belarusi $v$ predstavleniiakh molodezhi dvukh stran v XXI veke [Images of Russia and Belarus in the representations of the youth of the two countries in the XXI century], edited by I.A. Snezhkova, N.V. Shalygina, 17-41. Moscow: Institute of Ethnology and anthropology RAS.

Stefanenko, T.G. 2008. Sotsial'nye stereotipy i mezhetnicheskie otnosheniia [Social stereotypes and interethnic relations], 242-250. Moscow: Izdatelstvo Moskovskogo universitetata. 